\title{
Emerging Actions And Energy Strategies For Sustainable Development Of Sakarya City, Turkey: A SWOT Analysis
}

Ceyda Aksoy Tırmıkçı ( $\sim$ caksoy@sakarya.edu.tr)

Sakarya University

Original article

Keywords: building sector, climate change, greenhouse gas emissions, local adaptation, renewable energy, SWOT analysis, transportation sector

Posted Date: June 8th, 2021

DOI: https://doi.org/10.21203/rs.3.rs-508575/v1

License: (a) (i) This work is licensed under a Creative Commons Attribution 4.0 International License.

Read Full License 


\section{Abstract}

Background: Turkey has been one of the earliest participants of the international climate policy process, since the Ministerial Conference on Atmospheric Pollution and Climate Change held in 1989. The country has prepared strategy documents, actions plans, sectoral policies and projects to detect and adapt climate change effects. However, any of this has not turned into a main plan to support climate change mitigation on an international scale. The purpose of this paper is to identify local climate change mitigation strategies of Sakarya city, Turkey by strengths, weaknesses, opportunities and threats (SWOT) analysis. For this purpose, relevant information were gathered from Covenant of Mayors, greenhouse gas inventories of the city, National Energy Efficiency Action Plan, online workshop with 44 local stakeholders from private sector and local universities held on 13.10.2020.

Results: Transportation sector action plans proposed within SWOT analysis promise to decrease local transportation-based emissions by $27 \%$ compared to 2017 and by $26 \%$ compared to 2030 business as usual (BAU) Scenario. Buildings sector action plans proposed within SWOT analysis promises to decrease local building-sector based emissions by $20 \%$ compared to 2017 and by $33 \%$ compared to 2030 BAU Scenario. All mitigation strategies proposed within SWOT analysis promises to decrease local total emissions by $24 \%$ compared to 2017 and by $28 \%$ compared to 2030 BAU Scenario.

Conclusion: The results emphasize the importance of the cross-link between local adaptation and mitigation in terms of energy demand and energy-based emissions on national and international scale. This paper proposes that developing complete greenhouse gas inventories by accurate data within current technologies like the Internet of Things (IOT) and formulating climate change targets accordingly is the key to achieve the adaptation of local mitigation plans. In conclusion, it is emphasized that efforts to monitor, to report and to develop local mitigation legislations will determine the success rate of national sustainable development goals.

\section{Introduction}

The last decade has seen a critical level of global warming between 0.8 and 1.2 degrees Celsius representing alarming anthropogenic degradation of climate system (Intergovernmental Panel on Climate Change Summary for policymakers 2018). The Paris Agreement aims to limit this warming well below 2 degrees Celsius above pre-industrial levels to avoid dangerous degradation levels (Paris Agreement 2015). Recent climate change mitigation studies support that the world must commit to a rapid decarbonisation agenda to reach the goal of Paris Agreement (Kriegler, E et al. 2014, Nukusheva, A et al.2020, Riahi, K et al. 2017, Rogelj, J et al. 2015a, Skjærseth, JB 2021).

Burning fossil fuel resources for electricity and heat is the main driver of climate change (Dmitrii, B et al. 2021, Hanna, B et al. 2020). The records indicate that emissions from these sectors have reached to a historic value, 33.1 Gt CO2eq in 2019 (International Energy Agency, $\mathrm{CO}_{2}$ emissions 2019). However, the latest data show that global energy based $\mathrm{CO} 2$ emissions dropped dramatically in the first quarter of 
2020, due to the declines in global energy demand by the pandemic recession in global economic activity and mobility. It is estimated that the lowest value since 2010 will be recorded by the end of $2020,30.6 \mathrm{Gt}$, almost 8\% lower than the historic value in 2019 (International Energy Agency, Global Energy Review 2020). In this context, structural decline in emissions must be at the of political agenda to avoid a rebound as the world comes out the pandemic recession.

The future of energy demand and energy-based emissions are dependent on climate change adaptation actions by all levels of governments from local to national. There is a widespread agreement that adaptation comprises of interactions between social, cultural, economic processes by stakeholders and local governments (Liu, Y et al. 2020). Therefore, in order to mitigate climate change with resilient communities, it is required to understand how action plans work locally (Barnett, J 2010).

Sakarya is a city in Turkey located in the Marmara Region with coordinates $40^{\circ} 41^{\prime} 50^{\prime \prime} \mathrm{N} 30^{\circ} 27^{\prime} 24^{\prime \prime} \mathrm{E}$. The city encompasses a total area of 4.823 square kilometers, an area which had a population of $1,029,650$ in 2019 and a population density of 211 inhabitants per square kilometer. The population of the city increased by $18.7 \%$ in 2019 and continues to increase due to labor demands in rapidly growing industry sector (Turkish Statistical Institute. Population, Annual Growth Rate and Sex Ratio 2019). Agriculture and industry have an important role in the city's economy. The share of agriculture and industry sectors in employed population of the city were reported $17 \%$ and $24 \%$ respectively. Sakarya is one of the developing cities of Turkey with $1.6 \%$ share in the country's gross domestic product (Republic of Turkey Sakarya Governorship, Briefing II 2019).

Sakarya Metropolitan Municipality (SMM) is a member of Covenant of Mayors which entered into force in 2018 to pursue the efforts to limit greenhouse gas emissions on a local scale and strengthen the national response to the threat of climate change. In this context, reducing emissions at least $40 \%$ by 2030 and transition to cleaner and more secure energy future have become urgent goals of the city in the short and medium term. In this paper, urgent action plans to achieve local climate change targets were proposed by conducting a "strengths, weaknesses, opportunities and threats (SWOT) analysis.

\section{Materials And Methods}

The SWOT analysis is a technique first presented by Albert Humphrey in the 1960s for decision making for complex strategic situations (Learned, EP 1969). The technique aims to develop action plans to increase strengths and to reduce or eliminate weaknesses by benefiting from opportunities and preventing threats (Dyson, RG 2004).

In this paper, the SWOT analysis technique was used to analyse the energy-based greenhouse gas emissions situation in Sakarya city, Turkey and to develop local action plans for reducing local emissions and contributing the national climate change targets. The strengths, the weaknesses, the opportunities and the threats were identified by gathering the main points of Covenant of Mayors, greenhouse gas inventories of Sakarya city, climate change targets of National Energy Efficiency Action Plan and outcomes of an online workshop with local stakeholders held on 13.10.2020. The workshop provided 
different opinions from 44 participants from city universities, local governmental agencies and local nongovernmental organizations. Mitigation activities and priority levels to be implemented within a sustainable energy action plan for the city were determined within the scope of the following working groups: buildings and industry, transportation and renewable energy (Table 1). Greenhouse gas emission assumptions for the targeted year 2030 were made based upon population growth rate, building and service sector growth rate, energy consumption trends in the last decade and legislative changes in the jurisdiction of SMM.

\section{Table 1. SWOT Analysis Matrix}




\begin{tabular}{|c|c|c|c|c|}
\hline Segments & Strengths & Weaknesses & Opportunities & Threats \\
\hline Transportation & $\begin{array}{l}\text {-low public transport } \\
\text { fees } \\
\text {-age profile of the bus } \\
\text { fleet } \\
\text {-wide transportation } \\
\text { network } \\
\text {-bicycle infrastructures }\end{array}$ & $\begin{array}{l}\text {-public transport } \\
\text { infrastructure } \\
\text { - } \\
\text { pedestrianization } \\
\text {-expertise in } \\
\text { transportation } \\
\text { planning } \\
\text {-public } \\
\text { preference level } \\
\text {-rail system } \\
\text { - public transport } \\
\text { line planning } \\
\text { - financial } \\
\text { resources } \\
\text {-passenger } \\
\text { information } \\
\text { activities } \\
\text {-zoning planning } \\
\text { - alternative } \\
\text { energy sources } \\
\text { - bicycle paths }\end{array}$ & $\begin{array}{l}\text {-reduced fuel } \\
\text { costs with new } \\
\text { technologies } \\
\text {-government } \\
\text { support for } \\
\text { public } \\
\text { transportation } \\
\text {-geographical } \\
\text { structure } \\
\text {-urban master } \\
\text { transport plan }\end{array}$ & $\begin{array}{l}\text {-comfort of } \\
\text { private } \\
\text { transportation } \\
\text { - legal } \\
\text { legislations } \\
\text {-challenges in } \\
\text { rail transport } \\
\text {-local resistance } \\
\text { to } \\
\text { pedetrianization } \\
\text { and bicycle } \\
\text { projects }\end{array}$ \\
\hline Buildings & $\begin{array}{l}\text {-vision and } \\
\text { infrastructure for } \\
\text { smart city plans } \\
\text {-municipality support } \\
\text { for innovation } \\
\text {-heat insulation for } \\
\text { current buildings }\end{array}$ & $\begin{array}{l}\text {-financial } \\
\text { resources } \\
\text {-growth rate of } \\
\text { the city } \\
\text { - experienced } \\
\text { staff members } \\
\text {-action plan: no } \\
\text { strategy for } \\
\text { urban } \\
\text { transformation } \\
\text {-university } \\
\text { cooperation } \\
\text {-geographical } \\
\text { information } \\
\text { system } \\
\text {-reconstruction } \\
\text { controls }\end{array}$ & $\begin{array}{l}\text {-sustainable } \\
\text { design } \\
\text { standards for } \\
\text { new residential } \\
\text { areas } \\
\text {-renovation of } \\
\text { current buildings } \\
\text { with low } \\
\text { emission } \\
\text { technologies } \\
\text {-urban energy } \\
\text { transformation } \\
\text {-energy efficient } \\
\text { lighting systems } \\
\text { for current } \\
\text { buildings } \\
\text {-North Anatolia } \\
\text { fault line }\end{array}$ & $\begin{array}{l}\text {-illegal housing } \\
\text {-agricultural } \\
\text { land } \\
\text {-local interest in } \\
\text { urban energy } \\
\text { transformation } \\
\text {-uncontrolled } \\
\text { industrial shift } \\
\text { from Kocaeli } \\
\text { and istanbul }\end{array}$ \\
\hline
\end{tabular}


-local energy

performance

certificate

regulation

-environmental

impact analysis

Renewable -energy efficient street

Energy

lighting
-sustainable energy
from organic waste
materials: one
operating integrated
solid waste
management system
-heat and electricity
production from
current landfill area
regular waste
(electronic, oil, battery
and tie) collection
-student awareness

-renewable and
low carbon
energy transform
in residential
areas
-investment
costs
-rapid growth in
urbanization and
energy demand

-renewable

energy

applications in

municipal

buildings and

subsidiaries

-Renewable

Energy Trade

Agreement

-cooperation

between

municipality and

university

-midterm and

long term energy

transform

strategies with

infrastructure

companies

-sustainable

energy potential

from organic

waste

-interaction of

students with

their social

environment

-experts in

renewable

energy from

local universities -growth rate of natural gas

demand for

heating

-increase in bagless, unpermitted coal demand

-quality of coal available in the market

-experienced staff for special waste collection

-social

awareness

To evaluate the impact of action plans proposed in this paper, 2017 was selected as the reference year to compare the emission reduction targets. The direct and indirect greenhouse gas emissions of each sector were calculated by multiplying the final energy consumption by the corresponding emission factor. All $\mathrm{CO}_{2}, \mathrm{CH}_{4}$ and $\mathrm{N}_{2} \mathrm{O}$ emissions were calculated for all fuel types together using the IPCC emission factors in the Fifth Assessment Report (AR5). 


\section{Results}

\subsection{Transportation}

Sakarya Greenhouse Gas Emissions Inventory 2019 indicated that transportation sector is responsible for $27.5 \%$ of total emissions of the city with an energy consumption record 4,867,923 MWh. Growth rates of greenhouse gas emissions by transportation units were recorded $1 \%$ by municipal diesel fuelled vehicle fleet, $2 \%$ by municipal electric vehicle fleet, $3 \%$ public transport diesel fuelled vehicle fleet, $3 \%$ public transport electric vehicle fleet, $1.5 \%$ private diesel fuelled vehicles, $1 \%$ private diesel fuelled logistical vehicles, $1 \%$ private gasoline powered vehicles and 1\% private LPG vehicles (Figure 1). Although diesel fuel demand of the city decreased from 2017 to 2019, transportation shares, 1,5 million tCO2eq, are still the second in total emissions in parallel with the growth rates of urbanization and industry. SMM aims to decrease transportation-based emissions to 369,288 tCO2eq by 2030 within Covenant of Mayors.

Republic of Turkey Ministry of Energy and Natural Resources announced the urgent transportation sector actions as follows (Turkish Republic Ministry of Energy and Natural Resources. National Energy Efficiency Action Plan 2017-2023):

- energy efficient vehicle incentives: low taxation for low emission vehicles, raising social awareness for electric and hybrid vehicles

- comparative analysis of alternative fuel resources and new technologies

- improving pedestrian and bike transport: building new pedestrian and bike paths integrated with public transport nationwide.

- reducing traffic congestion in cities: measures to deter entry into city centers, parking lot cautions, dissemination of smart transportation system applications

- expanding public transportation

This paper proposes urgent local transport action plans for Sakarya city in Table 2 on the basis of SWOT analysis results in Table 1.

Main transport plan of Sakarya city was put into practice in 2011. The city has experienced rapid growth in urbanization, industry and traffic density since then. Therefore, it is urgent to put Action Plan 1 in place in parallel with zoning plans of the city. The owner and implementer of this plan is SMM and the key for the success here is to increase the number of experienced staff in the field.

Public transportation utilization rate of Sakarya city was recorded 9\% in 2019. The target of Action Plan 2 is to increase this rate to a minimum record $35 \%$ by 2024 . The priority actions within this plan is to optimize public transportation routes, establish new public transport lines for urban transformation areas, increase the number of public buses, transfer new technologies and build a rail system. The number of private transportation vehicles in the city are more than the number of public transportation vehicles-1050 private buses, 632 private minibuses and 362 taxis (Sakarya Metropolitan Municipality. Strategic Plan 2020-2024). The very low public utilization rate, $9 \%$, indicates that local people mostly prefer private 
transportation vehicles. The results of the workshop indicate that private transportation vehicles provide time savings in comparison with public transport modes. Action Plan 2 proposes to improve public transportation with new public transit modes and reduce at least $50 \mathrm{MtCO}_{2}$ eq of transportation-based emissions.

\section{Table 2. Transportation Sector Action Plans for Sakarya City}

\begin{tabular}{|ll|}
\hline Action Plan 1 & reviewing main transport plan and revising public transport plan \\
\hline Action Plan 2 & increasing public transport utilization rate \\
\hline Action Plan 3 & replacing public transport with energy efficient vehicles \\
\hline Action Plan 4 & initiating fast-charging station infrastructure studies \\
\hline Action Plan 5 & increasing bike transport shares \\
\hline Action Plan 6 & increasing pedestrian transport \\
\hline Action Plan 7 & developing low carbon vehicle sharing systems \\
\hline Action Plan 8 & providing economic driving techniques trainings \\
\hline Action Plan 9 & organizing social activities to increase social awareness \\
\hline
\end{tabular}

Public transportation utilization rate of Sakarya city was recorded 9\% in 2019. The target of Action Plan 2 is to increase this rate to a minimum record $35 \%$ by 2024 . The priority actions within this plan is to optimize public transportation routes, establish new public transport lines for urban transformation areas, increase the number of public buses, transfer new technologies and build a rail system. The number of private transportation vehicles in the city are more than the number of public transportation vehicles-1050 private buses, 632 private minibuses and 362 taxis (Sakarya Metropolitan Municipality. Strategic Plan 2020-2024). The very low public utilization rate, $9 \%$, indicates that local people mostly prefer private transportation vehicles. The results of the workshop indicate that private transportation vehicles provide time savings in comparison with public transport modes. Action Plan 2 proposes to improve public transportation with new public transit modes and reduce at least $50 \mathrm{MtCO}$ eq of transportation-based emissions.

Current technologies entering the transit industry offer great improvements in fuel economy of vehicles. Action Plan 3 targets to achieve considerable reductions in fleet fuel consumption by changing fleet buses and minibuses with new vehicles, more efficient vehicles in the short term and hybrid-electric vehicles in the medium term. It is expected to save 1,157 tCO2eq and 42,716 tCO2eq transportation-based emissions by low carbon transformation and by hybrid-electric transformation in public transport fleet respectively.

It is a fact that switching from conventional polluting vehicles to electric powered vehicles is a near future trend driven primarily by growing concerns about climate change. However, the transformation is likely to 
be time consuming and uncertain in locations where charging process is more difficult. In Sakarya city, fast-charging stations just emerged in some locations like shopping malls, hotels and highway side facilities. Action Plan 4 targets to support infrastructure studies to extend electric vehicle transformation in the city. The success of all the action plans above is depended on public awareness and acceptance. Activities to improve the social infrastructure to develop and/or transform transportation modes are vital for green mobility. Safe and economic training is a powerful social infrastructure tool of transportation to reduce use of fossil fuels and transport-based emissions. Action Plan 8 targets to train all drivers in the city and in particular drivers of public transportation modes. Current researches indicate that efficient driving behaviours can reduce use of fossil fuels by $5 \%$ and $10 \%$ for moderate driving styles and by almost $20 \%$ for aggressive driving styles (Gonder, $J$ et al. 2011). Training passengers and pedestrians is also a powerful tool to extend public transportation modes, bike transport and pedestrian transport. Action Plan 9 targets to organize training activities at schools for raising social awareness of young people of the society and to organize bike events to incentivize local people to cycling.

Sakarya city has a favourable topological structure for cycling. The municipal corporation developed a bicycle share system called SAKBIS which provides 110 bikes and 15 stations in different locations of the city. The results of the workshop indicate that the application received public acceptance and reached over 120 thousand accesses (Sakarya Metropolitan Municipality. Strategic Plan 2020-2024). Action Plan 5 targets to stimulate cycling and discouraging the use of private cars. In this context, urgent actions are determined to improve the physical infrastructure as well as the physical. Building new cycle ways, bike parking and bike stations are the prior actions since cycling is one of the developing transport modes of the city. One of the key outcomes of the workshop is that many local people's perceptions of road safety acts a significant barrier to cycling. Therefore, the next action must be establishment of new bike friendly traffic regulations in the city. Besides, integration of SAKBIS with the other public transport modes is also an urgent action to discourage the use of private cars.

Walking is the oldest transportation mode and the primary for some people (Loukaitou-Sideris, 2020). However, there are significant barriers to pedestrian travel like the lack of access to sideways, lack of regulations on pedestrian safety, disintegration of sideways to the other public transport modes and disinterest in walking (Anciaes PR, 2016). Action Plan 6 presents urgent local actions to increase pedestrian travel in Sakarya city. Building sideways, integrating sideways with the other public transport modes and traffic calming are listed as the actions to improve the physical infrastructure. On the social infrastructure side, urgent actions to convey health and environmental messages to demonstrate that walking brings health benefits for all people and environmental benefits in all locations can help to raise social awareness.

Vehicle sharing is an emerging transportation system reducing fossil fuel uses, increasing safety and reducing operating costs (Jones EC, et al. 2019, OECD/ITF 2017). In Sakarya city, only bicycle sharing system, SAKBIS, has been effectively operated. Action Plan 7 targets to increase vehicle station facilities, vehicle fleet size and customer demand sin the city in parallel with Action Plan 4 and Action Plan 5. Investigating management models to meet current and future mobility needs, cooperation with private 
enterprises to build flexible services and public incentivisation are determined the key actions to increase low and/or zero carbon vehicle sharing systems. However, achieving the targets of Action Plan 7 is depended on the progress of Action Plan 4 and Action Plan 5. It is expected to save almost 43,899 tCO2eq transportation-based emissions, if Action Plans 4-7 are successfully and urgently put into practice.

Figure 2 indicates greenhouse gas emissions by transportation sector of reference year 2017 and 2030 . From the figure, it can be concluded that transportation action plans proposed within SWOT analysis in Table 1 promises to decrease sector-based emissions by $27 \%$ compared to 2017 and by $26 \%$ compared to 2030 business as usual (BAU) Scenario.

\subsection{Buildings}

Sakarya Greenhouse Gas Emissions Inventory 2019 indicated that the largest contribution comes from building sector, $57.5 \%$ of total emissions of the city. The largest share of emissions by the sector came from industrial buildings to a record $27 \%$. Residential buildings and commercial buildings were responsible for $19.9 \%$ and $9.6 \%$ of total emissions by the sector. Building outdoor lighting systems and municipal buildings followed industry, residential buildings and commercial buildings with smallest shares of $0.7 \%$ and $0.3 \%$ respectively (Figure 3 ). Building based emissions increased from 1,372,910 tCO2eq in 2017 to $1,419,701$ tCO2eq in 2019. One of the sustainable development targets of the city is to decrease these emissions by at least 450,319 tCO2eq by 2030 .

In Sakarya city, there are 13 small industry areas and 6 organized industrial areas with a total area of 772 Hectares. Besides, new organized industrial areas in Karasu, Ferizli, Kaynarca and Akyazı towns are in the construction phase. Industry based emissions of the city is recorded 1,254,061 tCO2eq in 2019 (Sakarya Chamber of Commerce and Industry. 2018-2021 Strategic Plan). It is expected to record larger emissions in the following years, since the sector experiences a rapid growth.

This paper proposes urgent local buildings and industry action plans for Sakarya city in Table 3 on the basis SWOT analysis results in Table 1.

\section{Table 3. Buildings Sector Action Plans For Sakarya City}

\begin{tabular}{|ll|}
\hline Action Plan 1 & energy savings in residential buildings \\
\hline Action Plan 2 & energy savings in non-residential buildings \\
\hline Action Plan 3 & urban transformation \\
\hline Action Plan 4 & energy savings in municipal buildings \\
\hline Action Plan 5 & renovation of outdoor lighting systems \\
\hline
\end{tabular}

In Sakarya city, the largest share of residential buildings-based emissions came from fossil fuel use for heating- $65 \%$ of building based emissions and $20 \%$ of total emissions. Heating based energy demands of 
the city is larger than cooling energy demands due to climate conditions of the city. Therefore, thermal insulation can make a significant difference in the city's emissions by heating and cooling. Action Plan 1 proposes that thermal insulation for all buildings can reduce heating and cooling based energy demands and emissions of the city almost $533,186 \mathrm{MWh}$ and 121,112 tCO2eq at least by 2030 . Natural gas is the primary heating energy source of residential buildings in the city. An urgent action by Action Plan 1 is to complete natural gas transformation in all residential buildings in the city. It is estimated that 14.876 tCO2eq of building based emissions cane be saved by coal to natural gas transformation. The other urgent action of the plan is to renovate lighting systems of residential buildings. Energy efficient new lighting systems can provide 18,005 MWh energy savings and 9,254 tCO2eq emission savings by 2030 . However, Action Plan 1 underlines that social awareness is the key to succeed expected savings within the actions by the plan. It is likely to make additional 77,163 MWh energy savings and 39,662 tCO2eq emission savings by 2030 with social responsibility as well as heating, cooling and lighting savings. Therefore, activities to raise the awareness of local people are also listed within urgent actions to reduce carbon foot print by residential buildings.

Non-residential buildings, commercial buildings and industrial buildings, were responsible for $35 \%$ of the city's total building-based emissions. Action Plan 2 offers thermal insulation, renovation of lighting systems and social awareness activities to reduce total emissions by commercial buildings. Although cooling has a larger share in energy demands of non-residential buildings, thermal insulation can still provide 142,911 MWh energy savings and 30,689 tCO2eq emission savings. However, energy efficient lighting systems can make a significant change in total emissions of commercial buildings and industrial buildings by 161,671 tCO2eq savings. Previous studies held in Sakarya city proves that more than 40\% lighting energy saving is possible just using a daylight-controlled lighting automation system in such buildings (Yavuz, C et al. 2010, Yavuz, C et al.2012). Social responsibility is also vital in this sector with a potential of 94,360 MWh energy savings and 57,689 tCO2eq emission savings in addition to the savings by thermal insulation and energy efficient lighting energy systems.

Sakarya city lies down on the North Anatolian Fault System. Many earthquakes occurred in the last two millennia along the city and surrounding area (Karabacak, v. et al. 2019). Therefore, the priority of all buildings in the region is to withstand earthquakes (Özmen, $C$ et al. 2007). Action Plan 3 targets to integrate energy efficiency applications with design and construction stages of buildings which do not comply with earthquake regulations. Urban transformation plans including sustainable energy solutions can contribute to sustainability of the city in terms of safety, energy access and climate change concerns.

Sakarya Greenhouse Gas Emissions Inventory 2017 indicates that municipal buildings are responsible for 19,289 tCO2eq of total emissions of the city. Although actions to reduce emissions by municipal buildings do not promise significant savings, a potential of 3,906 tCO2eq, Action Plan 4 presents that these actions can support action plans to extend social awareness. Therefore, it is suggested to put place in urgent actions of thermal insulation, energy efficient lighting systems and social awareness activities to succeed Action Plan 1 and Action Plan 2. 
The share of outdoor lighting of municipal and public buildings in total emissions of the city was recorded 31,184 tCO2eq in 2017. Action Plan 5 targets to renovate outdoor lighting systems of all public buildings, since the government encourages corporations to make at least $15 \%$ outdoor lighting energy savings in parallel with the growth rate of electricity price of the country. An energy efficient outdoor lighting transformation with $15 \%$ energy savings can provide 11,500 tCO2eq emission savings to Sakarya city.

Figure 4 indicates greenhouse gas emissions by building sector of reference year 2017 and 2030. From the figure, it can be concluded that buildings sector action plans proposed within SWOT analysis in Table 1 promises to decrease building-sector based emissions by $20 \%$ compared to 2017 and by $33 \%$ compared to 2030 BAU Scenario.

\subsection{Renewable energy}

In 2019, total annual electricity consumption and greenhouse gas emissions by electricity generation of Sakarya city were recorded 3,144,306 MWh and 1,869,116 tCO2eq. The share of total annual electricity generation-based emissions in total city emissions was 40\% (Figure 5). Industrial sector makes the largest contribution with a $58 \%$ share and followed by commercial, residential and agricultural sectors.

In Sakarya city, solar and bioenergy technologies are promising to transform energy system of the city into a more sustainable one mainly by renewable energy sources. The annual mean solar radiation of the city is about $1450 \mathrm{kWh} / \mathrm{m} 2$, lower than Turkey's annual mean record but still a great potential comparing to Germany mean value (Figure 6) (Solar GIS, Solar resource maps of Turkey,Solar GIS, Solar resource maps of Germany). Bioenergy is an important source of sustainable energy in Sakarya city due to its significant potential of forest sources and non-forest sources (solid wastes, animal wastes and agricultural crop residues). In 2019, annual dry biomass po-tential of field crops and tree pruning wastes are recorded 974,990 tonnes and 28,304,823 tonnes respectively (Sakarya Chamber of Commerce and Industry, 2018-2021 Strategic Plan).

Republic of Turkey Ministry of Energy and Natural Resources 2019-2023 Strategic Plan aims to increase the share of renewables in electricity generation by at least $38.8 \%$. In this context, it is expected to reach a total installed renewable capacity of $56,804 \mathrm{MW}$ by $10,000 \mathrm{MW}$ solar photovoltaic, $11,883 \mathrm{MW}$ wind, 32,037 hydro and 2,884 geothermal and biomass (Turkish Republic Ministiry of Energy and Natural Resources. National Energy Efficiency Action Plan 2017-2023). Short term and midterm renewable energy targets of SMM Strategic Plan to increase the installed renewable capacity of the city coincide well with national energy goals.

This paper proposes urgent renewable energy action plans for Sakarya city in Table 4 on the basis of SWOT analysis results in Table 1.

\section{Table 4. Renewable Energy Sector Action Plans for Sakarya City}


Action Plan 1 solar photovoltaic energy applications in public buildings

Action Plan 2 solar photovoltaic energy applications in residential and non-residential buildings

Action Plan 3 green electricity tariffs

Action Plan 4 renovation of street lighting

Action Plan 5 electricity from municipal solid waste

In Sakarya city, the share of electricity in total energy demand and total emissions of public buildings are almost $16.8 \%$ and $33.1 \%$. Action Plan 1 offers that utilizing renewable energy sources as the primary energy source for electricity generation in municipal buildings and other public buildings can provide significant energy savings and consequently emission savings. It is likely to put urgent actions in place within Action Plan 1, since public buildings have some advantages in parallel with relevant regulations relating to unlicensed electricity generation based on renewables. Current legislation allows unlicensed applications up to $5 \mathrm{MW}$ installed power (Republic of Turkey Energy Market Regulatory Authority, Electricity Legislation 2019). In this context, the prior target is to install $25,000 \mathrm{kWp}$ solar photovoltaic energy systems in municipal buildings and the other public buildings by 2030 . To achieve this target, the first action must be to determine primary and proper buildings for solar PV applications by a full feasibility study. Then, resources must be investigated to ensure the rapid transition to solar PV energy in the selected buildings. Finally, tendering schemes must be developed for installation, operation and maintenance stages by typical project experiences. There are several previous studies, regarding the best installation angles (Tirmikci, CA et al. 2019a) and mechanical preferences of PV systems (Tirmikci, CA et al. 2018b) for Sakarya city, that responsible authorities can easily use to find the best system match for the best building. Taking all actions into account the targeted solar PV capacity will provide at least a sum of 30,000 MWh annual mean electricity generation and 15,402 tCO2eq emission savings.

Residential and non-residential buildings are responsible for $41 \%$ of total electricity consumption and $40.9 \%$ of total energy-based emissions of Sakarya city. Action Plan 2 offers a rapid solar PV energy transition for these buildings by utilizing current legislation allowing unlicensed applications up to $5 \mathrm{MW}$ installed power. As in Action 1, doing a full feasibility study, resource investigation and developing tendering schemes are urgent actions for success. However, the city is in the process of urban transformation within relevant legislation relating disaster risk areas. This process to build new residential areas and to transform the risky building stock can be considered as an opportunity for energy transition. In this context, local governments subsidize PV applications at certain capacities in residential and non-residential buildings to speed up the transition. It is aimed to increase the installed solar PV capacity of residential and non-residential buildings by $175 \mathrm{MWp}$ by 2030 . The new capacity promises 240,000 MWh electricity generation and 107,940 tCO2eq emission savings annually.

Republic of Turkey Energy Market Regulatory Board approved a green tariff of $0.698 \mathrm{TL} / \mathrm{kW}$ which allows end users to source up their electricity from renewable resources. Action Plan 3 targets to increase renewable energy demand on the end customer side by increasing the number of green tariffs. The 
priority of the action plan is to extend greenest tariffs from energy suppliers that buy electricity certificate directly from renewable energy generators. Greenest tariffs tend to be more expensive due to the cost and efficiency of renewable energy generation systems. However, the demand for these tariffs are likely to increase in parallel with social awareness actions within local and national sustainable development plans to convince the end users that this price is worth paying. Besides, it is vital to increase the number of mixed tariffs from suppliers that provide end users mixed electricity from mix of renewable resources and fossil fuels. Although mixed tariffs do not promise to stimulate the development of renewables, they can speed the transition to a hundred percent renewable tariffs in Sakarya city where the number of green end users are very few. It is likely to save 514 tCO2eq emissions annually by a $1000 \mathrm{kWh}$ of electricity consumption of an end user from a greenest tariff.

Reports indicate that the share of street lighting in total energy demand of SMM is $15.8 \%$ which accounts for 31.184 tCO2eq/year. Action Plan 4 targets to reduce the street lighting demands by renovating the street lighting systems. The prior action must be to analyse lighting energy demands and to do a feasibility analysis of lighting systems regionally. In the next step, lighting systems must be renovated as per the order of priority given by feasibility reports. It is likely to provide $18.309 \mathrm{kWh}$ energy savings and 9.41 tCO2eq emission savings annually by renovation of at least half of street lighting systems in the city.

SMM generates electricity from municipal solid waste with an installed capacity of $3.87 \mathrm{MW}$ at Sakarya Integrated Solid Waste Management Centre (SEKAY). Action Plan 5 offers that increasing the installed capacity of generation from municipal solid waste can be a rapid solution in short term to decrease the carbon foot print of the city in the process of renewable energy transition in all sectors.

Figure 7 indicates total greenhouse gas emissions of reference year 2017 and 2030. From the figure, it can be concluded that all action plans proposed within SWOT analysis in Table 1 promises to decrease total emissions by $24 \%$ compared to 2017 and by $28 \%$ compared to 2030 BAU Scenario.

\section{Conclusion}

In Sakarya city, the largest contribution to energy-based emissions comes from building sector, $57.5 \%$ of total emissions of the city. Transportation sector follows the building sector with a significant share, $27.5 \%$. This paper presents local action plans to reduce the emissions by building and transport sectors and to support energy transformation set out in National Energy Efficiency Action Plan. Action plans were developed by a SWOT analysis with information gathering the main points of Covenant of Mayors, climate change target of National Energy Action Plan and an online workshop with local stakeholders. The calculations derived from proposed action plans indicate that preventive measures by local government can reduce emission per capita dramatically.

The results of SWOT analysis in this paper emphasize that local policies have the key role to build resilient cities against the climate change combat with economies of scale, environmental sustainability and educated society. The first step for local adaptation and mitigation in climate policy is to develop 
complete and accurate greenhouse gas inventories. In this context it is meaningful to real-time monitor and analyse emissions with current technologies like the Internet of Things (IoT) which offer a promising method to real-time monitoring. The next step is to formulate climate change targets and actions considering the cross-link between local adaptation and mitigation. Final steps are monitoring, reporting and developing adaptive local legislations accordingly (Fig. 8). In order to successfully implement climate change mitigation policies and activities, it is important to develop clearly stated assessment and reporting requirements and to develop monitoring methods that will provide performance evaluations. On a local scale, efforts to measure the progress in the practices and the cooperation between local government, private sector and local educational institutions will determine the contribution of local stakeholders and the success rate of sustainable development goals.

\section{Declarations}

\section{Ethics approval and consent to participate}

Not applicable

\section{Consent for publication}

Not applicable

\section{Availability of data and materials}

The data that support the findings of this study are available from Sakarya Metropolitan Municipality but restrictions apply to the availability of these data, which were used under license for the current study, and so are not publicly available. Data are however available from the authors upon reasonable request and with permission of Sakarya Metropolitan Municipality.

\section{Competing interests}

The author declare that they have no competing interests.

\section{Funding}

Not applicable.

\section{Authors' contributions}

Concept - CAT, Data Collection \&/or Processing - CAT., Literature Search - CAT., Writing - CAT

\section{Acknowledgments}

The author would like to thank Sakarya Metropolitan Municipality for providing valuable inputs of greenhouse gas inventories of the city between 2017 and 2019 to this study. The author would also like to acknowledge all participants involved in online workshop held on 13.10.2020. 


\section{References}

1. Anciaes PR, Boniface S, Dhanani A, Mindell JS, Groce N (2016). Urban transport and community severance: linking research and policy to link people and places. J. Transp. Health, 3(3): 268-277.

2. Barnett J (2010). Adapting to climate change: three key challenges for research and policy-an editorial essay. Wiley Interdiscip. Rev. Clim. Chang., 1(3): 314-317.

3. Dmitrii B, Manish R, Arman A, Ashish G et al. (2021). Low-cost renewable electricity as the key driver of the global energy transition towards sustainability. Energy,120467.

4. Dyson RG (2004). Strategic development and SWOT analysis at the University of Warwick. Eur J Oper Res, 152(3): 631-640.

5. Gonder J, Earleywine M, Sparks W (2011). Final report on the fuel saving effectiveness of various driver feedback approaches. National Renewable Energy Laboratory.

6. Hanna B, Pao-Yu O (2020). The political economy of coal in Poland: Drivers and barriers for a shift away from fossil fuels. Energy Policy, 144:111621.

7. Intergovernmental Panel on Climate Change. Summary for policymakers, in Global Warming of $1.5^{\circ} \mathrm{C}$. An IPCC Special Report on the impacts of global warming of $1.5^{\circ} \mathrm{C}$ above pre-industrial levels and related global greenhouse gas emission pathways, in the context of strengthening the global response to the threat of climate change, sustainable development, and efforts to eradicate poverty World Meteorological Organization. Geneva, Switzerland, (2018).

8. International Energy Agency (2019), OECD/IEA, Paris, France. CO2 emissions. Retrieved 10.01.2021 from https ://www.iea.org. March 2020

9. International Energy Agency (2020), OECD/IEA, Paris, France. Global Energy Review. Retrieved 20.01.2021 from https ://www.iea.org.March 2020

10. Jones EC, Leibowicz BD (2019). Contributions of shared autonomous vehicles to climate change mitigation," Transportation Research Part D: Transport and Environment, 72:279-298.

11. Karabacak V, Uysal IT, Mutlu H, Ünal İmer E, Dirik RK, Feng Y (2019). Are U-Th dates correlated with historical records of earthquakes? Constraints from coseismic carbonateveins within the North Anatolian Fault Zone. Tectonics, 38: 2431-2448.

12. Kriegler E, Weyant JP, Blanford GJ et al. (2014). The role of technology for achieving climate policy objectives: overview of the EMF 27 study on global technology and climate policy strategies. Climatic Change, 123:353-367.

13. Learned EP (1969). Business policy: text and cases. RD Irwin.

14. Liu Y, Gupta H, Springer E, Wagener T (2008). Linking science with environmental decision making: experiences from an integrated modeling approach to supporting sustainable water resources management. Environ. Model. Software, 23:846-858.

15. Loukaitou-Sideris A (2020). Special issue on walking. Transport Reviews, 40(2):131-134.

16. Nukusheva, A., llyassova, G., Rustembekova, D. et al (2020). Global warming problem faced by the international community: international legal aspect. Int Environ Agreements. 
https://doi.org/10.1007/s10784-020-09500-9

17. OECD/ITF (2017). Transition to shared mobility. Retrieved 10.12.2020 from https://www.itfoecd.org/sites/default/files/docs/transition-shared-mobility.pdf

18. Özmen C, Ünay Ai (2007). Commonly encountered seismic design faults due to the architectural design of residential buildings in Turkey. Building and Environment, 42(3):1406-1416.

19. Paris Agreement, Durban Platform for Enhanced Action (Decision 1/CP.17), Adoption of the Paris Agreement FCCC/CP/2015/L.9/Rev.1 (United Nations Framework Convention on Climate Change, 2015), UNFCCC Secretariat, Bonn, Germany, (2015).

20. Republic of Turkey Energy Market Regulatory Authority. Electricity Legislation 2019. Retrieved 15.02.2021 from https://www.epdk.gov.tr

21. Republic of Turkey Sakarya Governorship. Briefing II (2019), pp.7-14. Retrieved 01.02.2021 from http://sakarya.gov.tr/kurumlar/sakarya.gov.tr/valilik/brifing/brifing_temmuz_2019.pdf

22. Riahi K, Van Vuuren DP, Kriegler E, Edmonds J, O'neill BC, Fujimori S, et al. (2017). The shared socioeconomic pathways and their energy, land use, and greenhouse gas emissions implications: an overview. Glob Environ Change, 42: 153-168.

23. Rogelj J, Luderer G, Pietzcker RC, Kriegler E, Schaeffer M, Krey V, Riahi K (2015a). Energy system transformations for limiting end-of-century warming to below $1.5^{\circ} \mathrm{C}$. Nat. Clim. Change, 5(6): 519527.

24. Sakarya Chamber of Commerce and Industry. 2018-2021 Strategic Plan. Retrieved 25.12.2021 from http://satso.org.tr

25. Sakarya Metropolitan Municipality. Strategic Plan 2020-2024. Retrieved 05.01.2021 from https://sakarya.bel.tr

26. Skjærseth, JB (2021) Towards a European Green Deal: The evolution of EU climate and energy policy mixes. Int Environ Agreements, 21:25-41.

27. Solar GIS. Solar resource maps of Turkey. Solar resource maps and GIS data for $180+$ countries 2019. Retrieved 10.02.2021 from https://solargis.com/maps-and-gis-data/download/turkey

28. Solar GIS. Solar resource maps of Germany. Solar resource maps and GIS data for 180+ countries 2019. Retrieved 10.02.2021 from https://solargis.com/maps-and-gis-data/download/germany

29. Tirmikci CA, Yavuz C (2018b). A mechanical design of an altitude-azimuth two axis solar tracking system for Sakarya, Turkey. International Journal of Mechanical Engineering and Robotics Research, 35:40.

30. Tirmikci CA, Yavuz C (2018a). Determining optimum tilt angles of solar surfaces in Sakarya, Turkey. Theoretical and Applied Climatology, 133:15.

31. Turkish Republic Ministiry of Energy and Natural Resources. National Energy Efficiency Action Plan 2017-2023. Retrieved 08.01.2021 from https://www.enerjiportali.com

32. Turkish Statistical Institute. Population, Annual Growth Rate and Sex Ratio (2019). Retrieved 15.01.2021 from https://www.tuik.gov.tr 
33. Yavuz C, Yanikoglu E, Guler O (2010). Determination of real energy saving potential of daylight responsive systems: a case study from Turkey. Light \& Engineering,18:99.

34. Yavuz C, Yanikoglu E, Guler O (2012). Evaluation of daylight responsive lighting control systems according to the results of a long term experiment. Light \& Engineering, 20: 75.

\section{Figures}

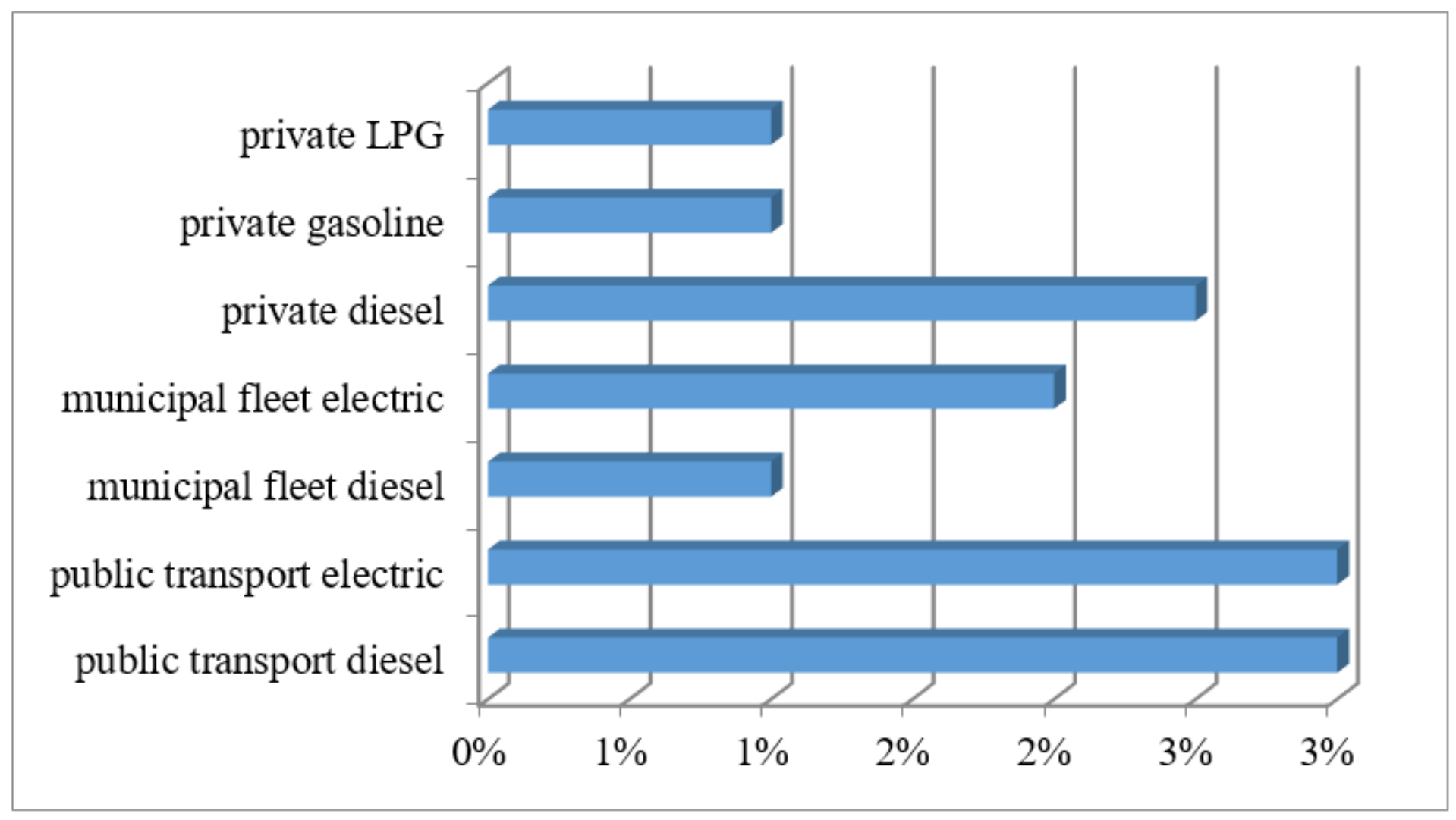

\section{Figure 1}

Growth rates of greenhouse gas emissions by transport units. 


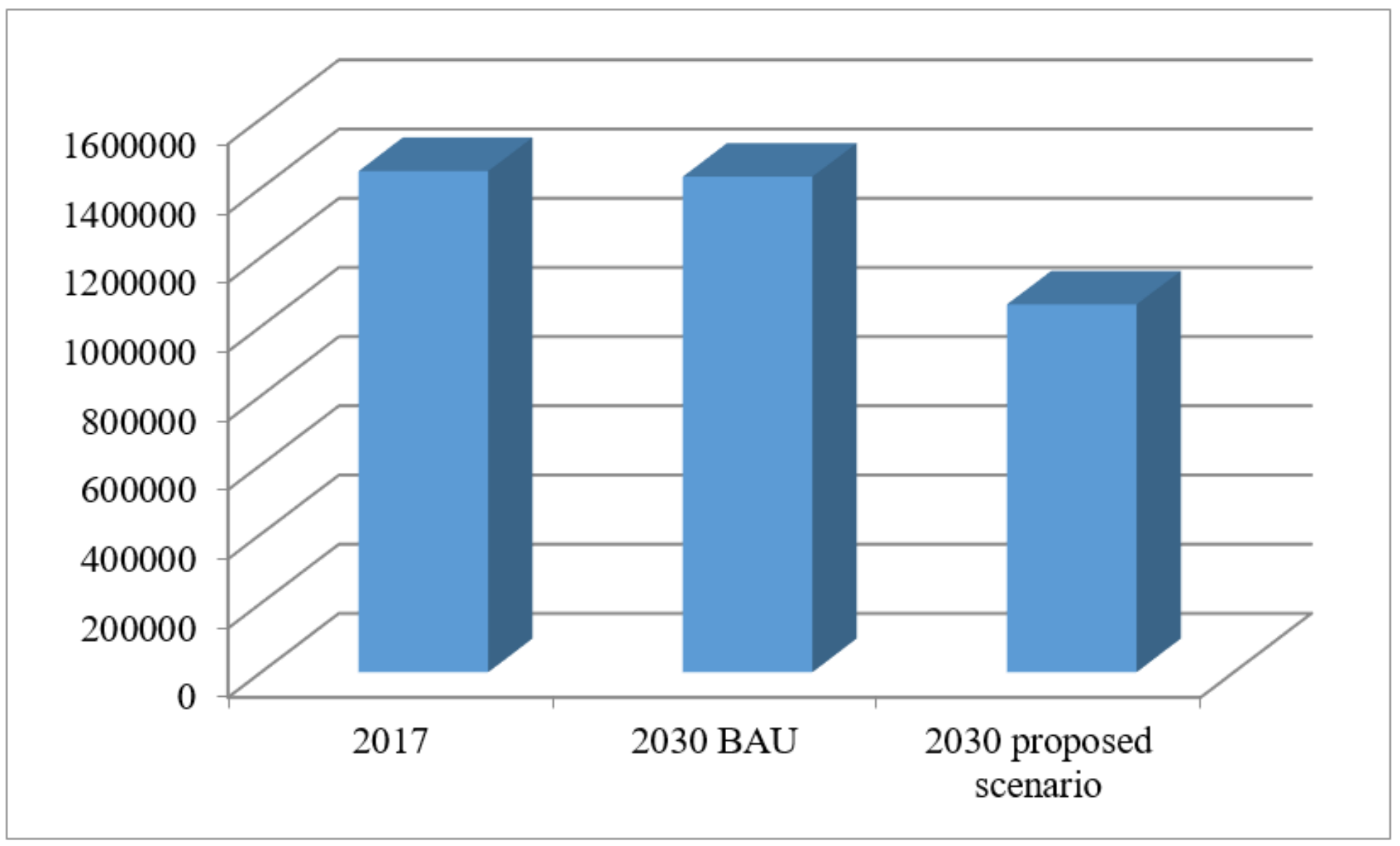

Figure 2

Greenhouse gas emissions by transportation sector of 2017, 2030 BAU and 2030 proposed scenario 
building outdoor lighting systems

commercial buildings

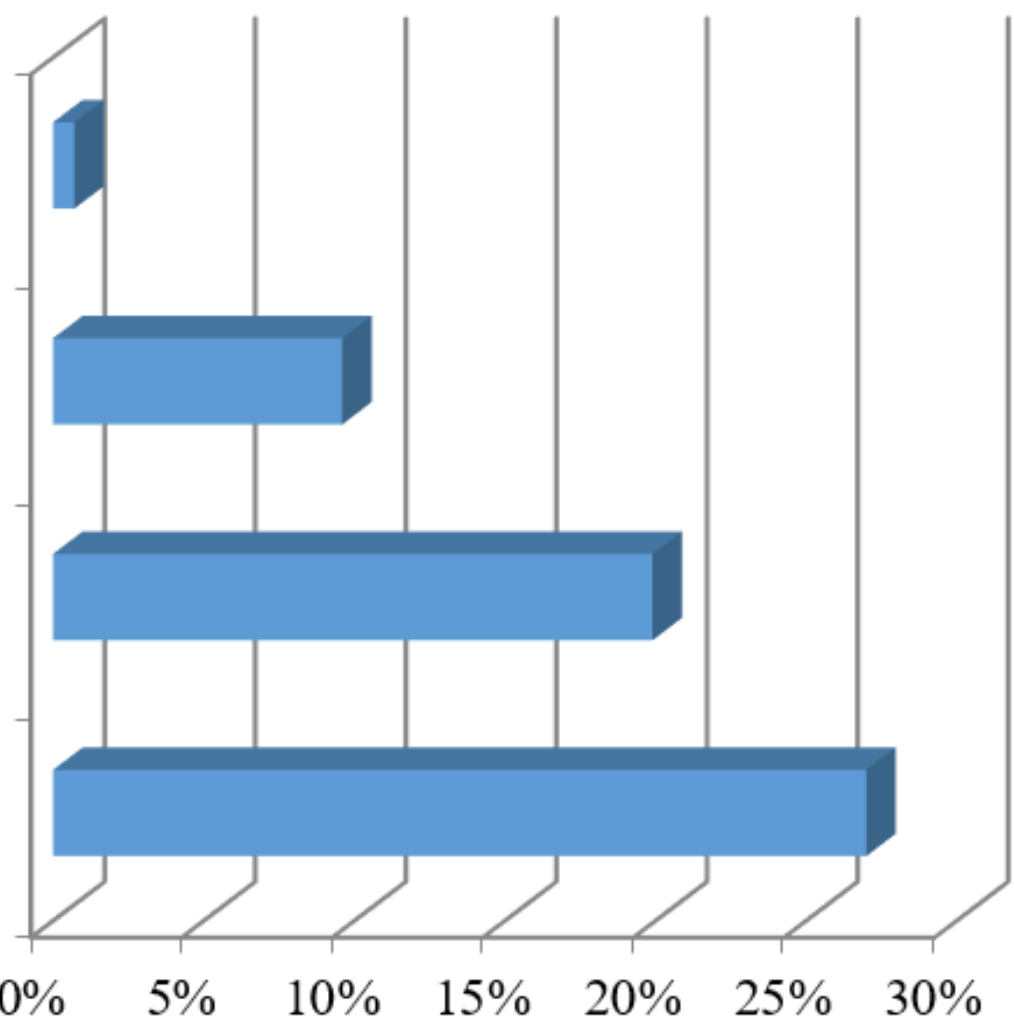

Figure 3

Sectoral shares of building based greenhouse gas emissions

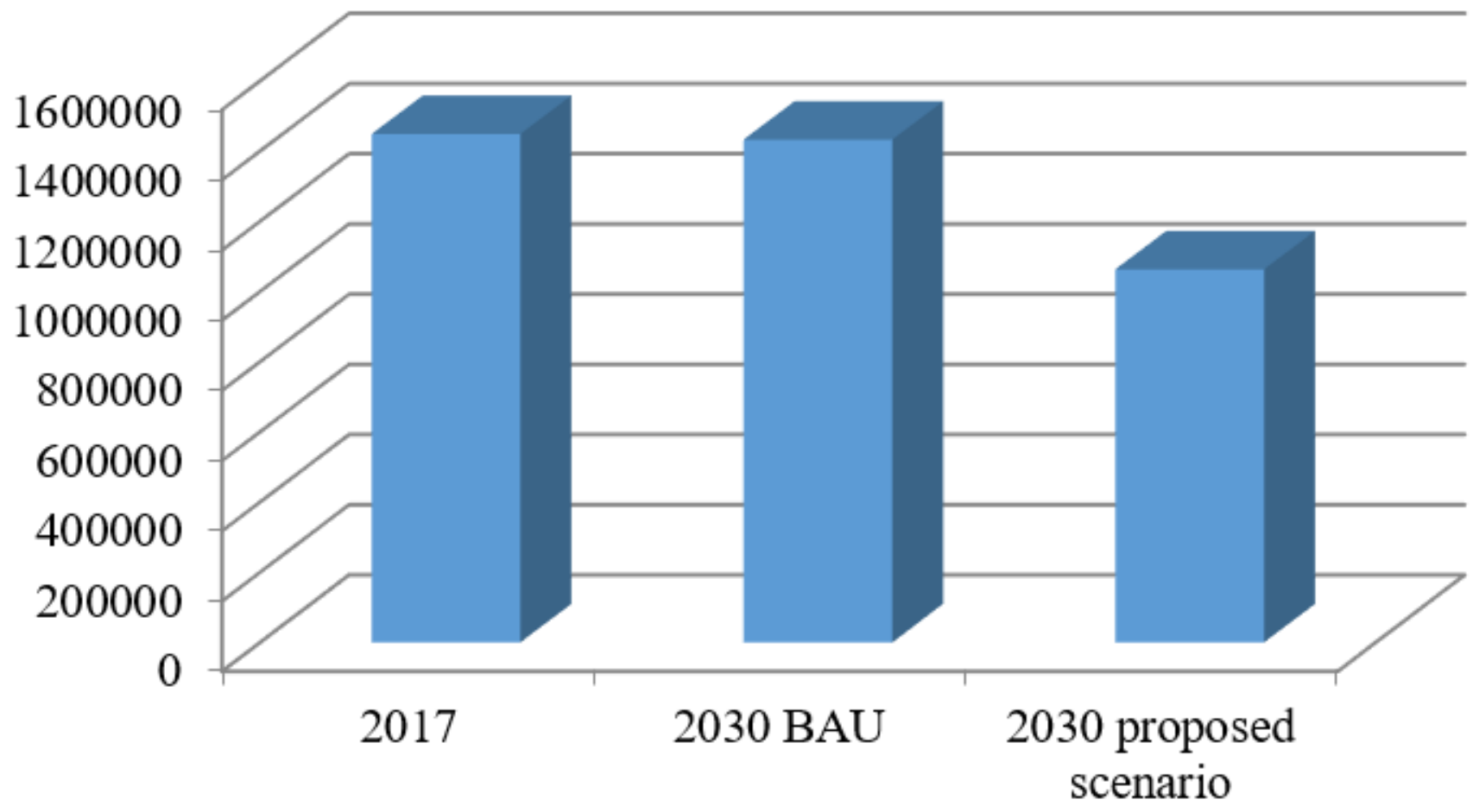


Figure 4

Greenhouse Gas Emissions by Buildings Sector of 2017, 2030 Bau and 2030 Proposed Scenario

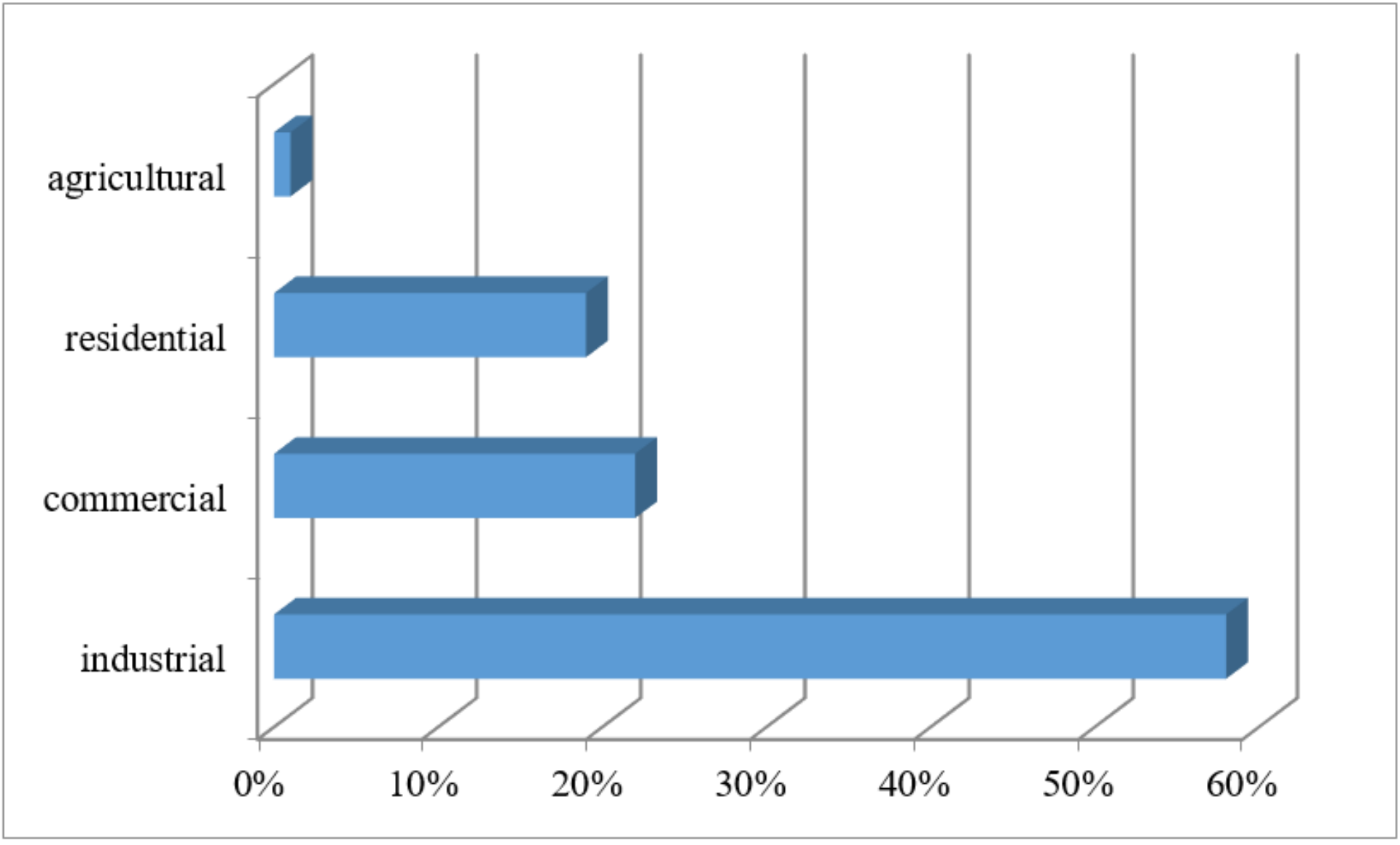

Figure 5

Sectoral Shares of Electricity Consumption Based Greenhouse Gas Emissions 


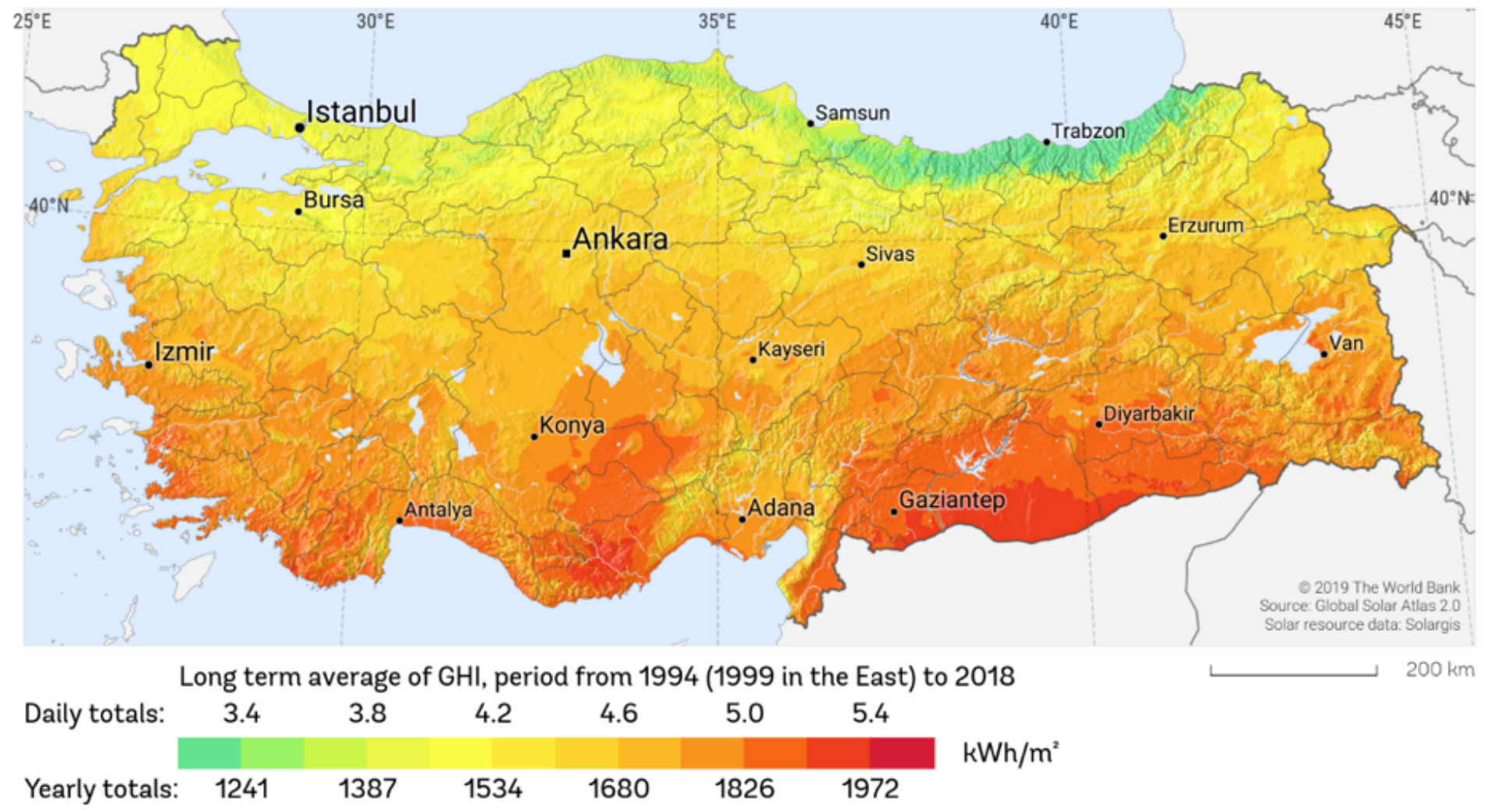

\section{Figure 6}

Global solar irradiation of Turkey [30] Note: The designations employed and the presentation of the material on this map do not imply the expression of any opinion whatsoever on the part of Research Square concerning the legal status of any country, territory, city or area or of its authorities, or concerning the delimitation of its frontiers or boundaries. This map has been provided by the authors. 


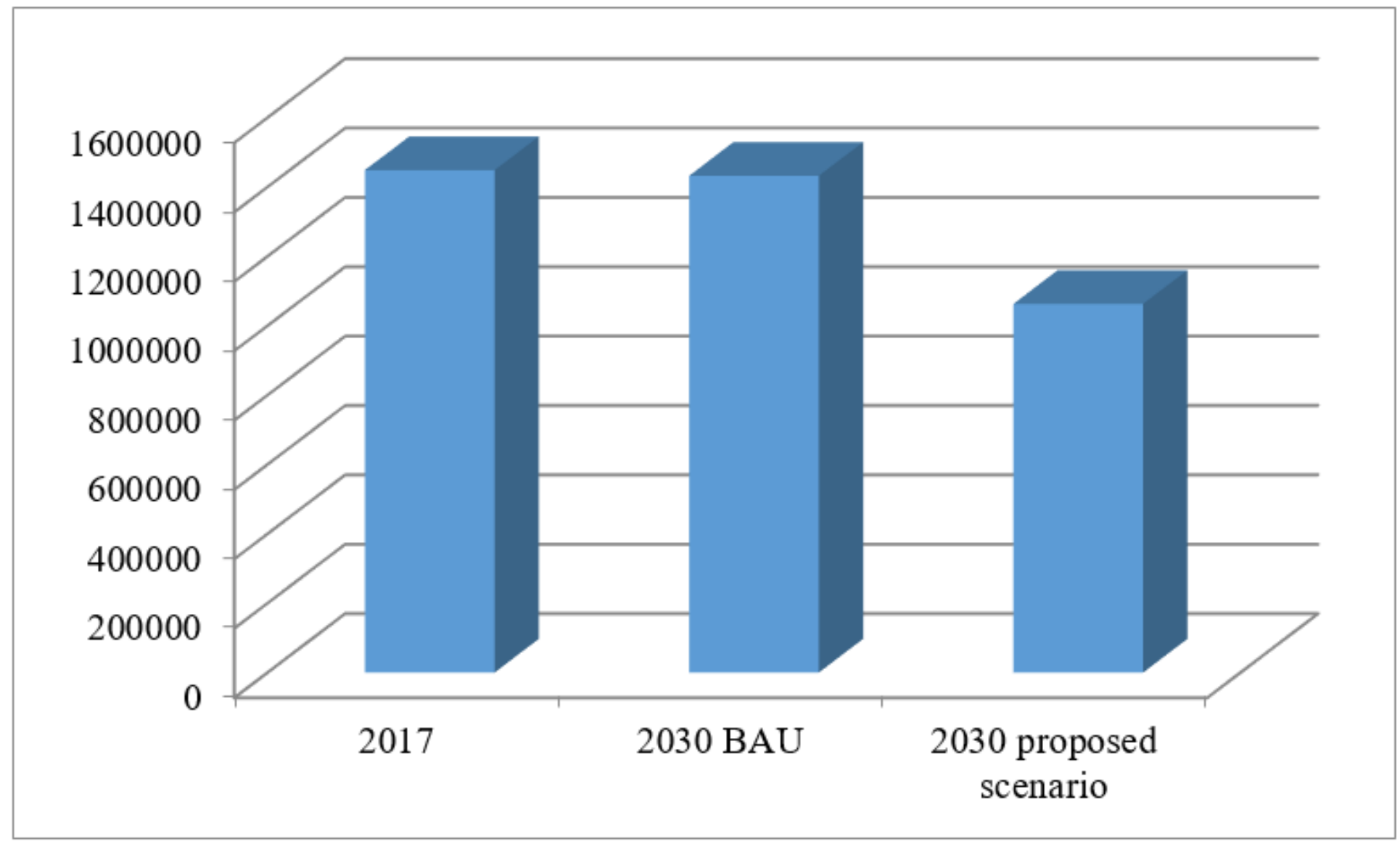

Figure 7

Total Greenhouse Gas Emissions of 2017, 2030 BAU and 2030 Proposed Scenario 


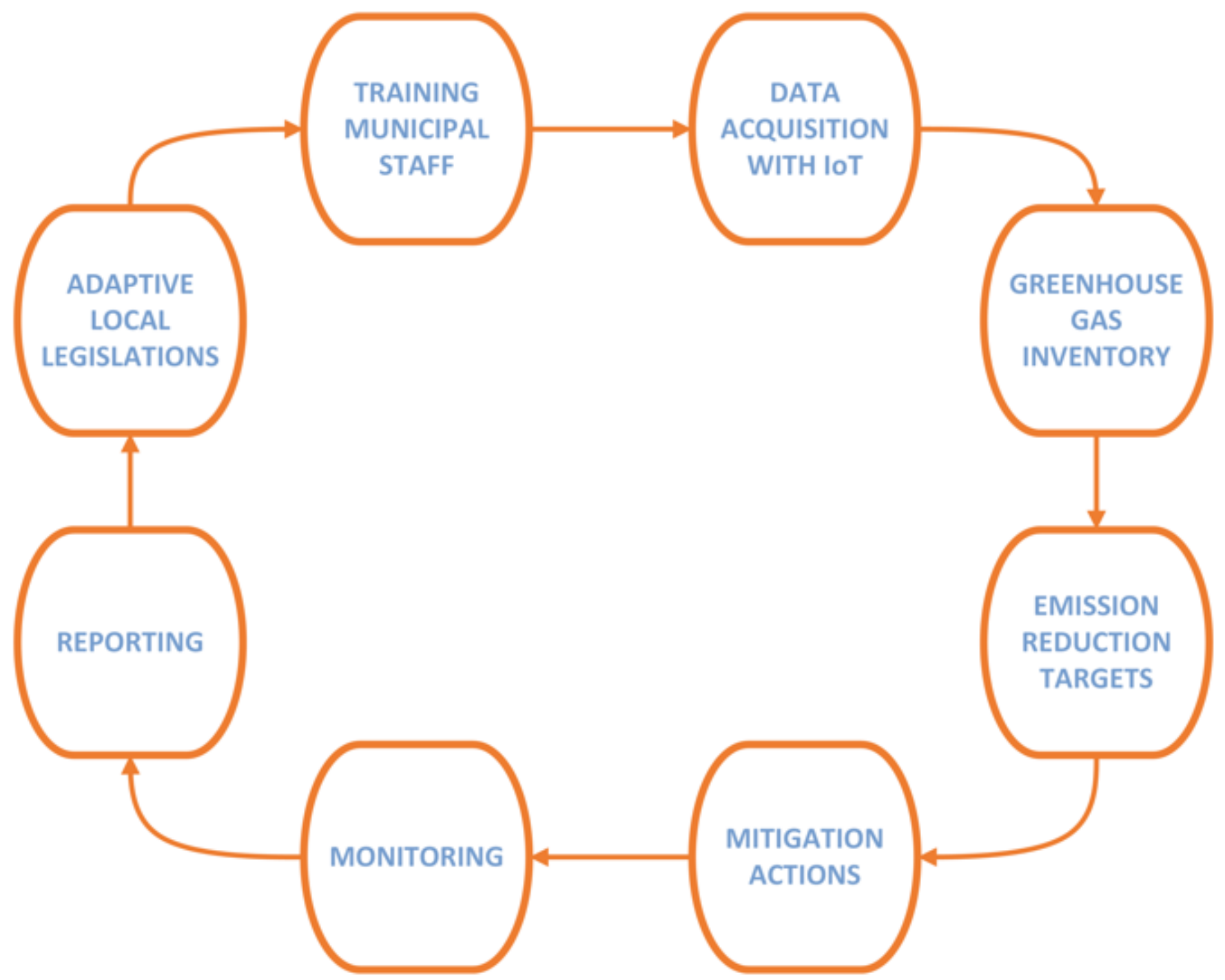

Figure 8

The proposed local climate change policy cycle 